\title{
PELATIHAN APLIKASI JASA KURIR ONLINE PADA PEGAWAI MINI MARKET BORNEO MART BANJARBARU
}

\author{
Mokhamad Ramdhani Raharjo, Ihda Innar Ridho, dan Fauzi Yusa Rahman \\ Fakultas Teknologi Informasi, Universitas Islam Kalimantan \\ Muhammad Arsyad Al Banjari Banjarmasin \\ E-mail : 007.ramdhani@gmail.com
}

\begin{abstract}
Application training of shipping services in orderly ordering using online application is something that must be known by business actors, especially mini business actors to improve the results of the business. The target of this training activity is the employee or employee of mini market borneo mart banjarbaru. With this training, employees are expected to understand and can operate the application of online courier services to products sold from goods ordered by the buyer. Benefits of dedication activities to be achieved is the target audience can operate the application well so that it becomes one of the efforts to improve employee performance of mini market borneo mart so that good impact to buyer or consumer in terms of satisfaction to service. From the result of the training, it can be concluded that the trainees saw the practice and some question and answer about the application that was held $88 \%$ of the participants can operate the material given.
\end{abstract}

Keywords: Online Courier, Employee, Mini Market

\section{PENDAHULUAN}

Pada era sekarang perkembangan ilmu pada bidang teknologi informasi dimanfaatkan oleh beberapa pelaku usaha atau beberapa perorangan sebagai alat untuk meningkatan hasil usahanya dengan memanfaatkan kemajuan pada bidang teknologi. Khususnya di Indonesia mulai bermunculan beberapa pelaku usaha di bidang jasa online seperti GO-JEK. Pada Awalnya GO-JEK didirikan pada awal tahun 2010 di Jakarta fokus pada jasa tukang ojek online dan akhirnya pada saat ini menyediakan jasa transportasi barang dan beberapa jasa lainya yang dimiliki oleh perusahaan GO-JEK tersebut. Berdasarkan perkembagan para pelaku usaha mulai memanfaatkan teknologi online untuk menawarkan jasanya, Mini Market Borneo Mart Banjarbaru juga perlu untuk bersaing dengan pelaku jasa lainya dengan menawarkan jasa kurir online yang dikususkan pada konsumen atau pelanggan Borneo Mart. Jasa yang ditawarkan dari fitur aplikasi ini berupa jasa pengiriman barang yang dilakukan oleh konsumen atau pembeli barang di Mini Market Borneo Mart. Karena tidak semua orang khususnya pegawai atau karyawan Borneo Mart bisa 
menggunakan aplikasi kurir berbasis online, maka dilakukan pelatihan penggunaan aplikasi jasa kurir online pada pegawai Mini Market Borneo Mart Banjarbaru.

\section{KHALAYAK SASARAN}

Pegawai atau karyawan Mini Market Borneo Mart Banjarbaru yang bertugas untuk mengisikan data transaksi pengiriman barang serta karyawan yang bertugas mengirimkan barang yang dibeli. Setalah karyawan yang bertugas mengisikan data transaksi pengiriman barang yang berisi alamat konsumen serta tanggal barang dikirim, Karyawan lain yang bertugas mengirimkan barang tersebut, kemudian memberikan status pada barang yang dikirim sudah selesai dilakukan.

\section{METODE}

Cara yang dilakukan untuk memberikan pelatihan aplikasi jasa pengiriman barang atau kurir secara online yaitu:

\section{Penjelasan Materi dan Tutorial Penggunaan}

Pelatih memberikan penjelasan terlebih dahulu kepada karyawan dengan memberikan buku petunjuk aplikasi dengan menjelaskan fungsifungsi aplikasi serta mempraktikan dengan memberikan contoh kepada karyawan .

\section{Praktek Mandiri}

Karyawan atau peserta mempraktekan penggunaan aplikasi mulai dari proses login admin dan transaksi pengelolaan data. Praktek transaksi pengelolaan data berupa proses simpan data konsumen dengan menyimpan biodata data yang tertera pada Kartu Tanda Penduduk konsumen serta proses transaksi permintaan konsumen untuk menggunakan jasa pengiriman barang.

\section{Tanya Jawab}

Karyawan atau Peserta kegiatan diberi kesempatan untuk bertanya kepada pelatih pada saat praktek penggunaan aplikasi.

\section{HASIL DAN PEMBAHASAN}

Dari pelaksanaan kegiatan yang telah dilaksanakan karyawan atau peserta dapat bekerja sama dengan baik dan atusias mengikuti pelatihan aplikasi karena aplikasi ini sangat membantu Mini Market Borneo Mart Banjarbaru untuk memberikan tingkat kepuasan kepada konsumen atau pelanggan yang sering belanja dimini market tersebut dengan adanya jasa pengiriman barang melalui aplikasi kurir online yang telah dimiliki. 


\section{FOTO KEGIATAN}
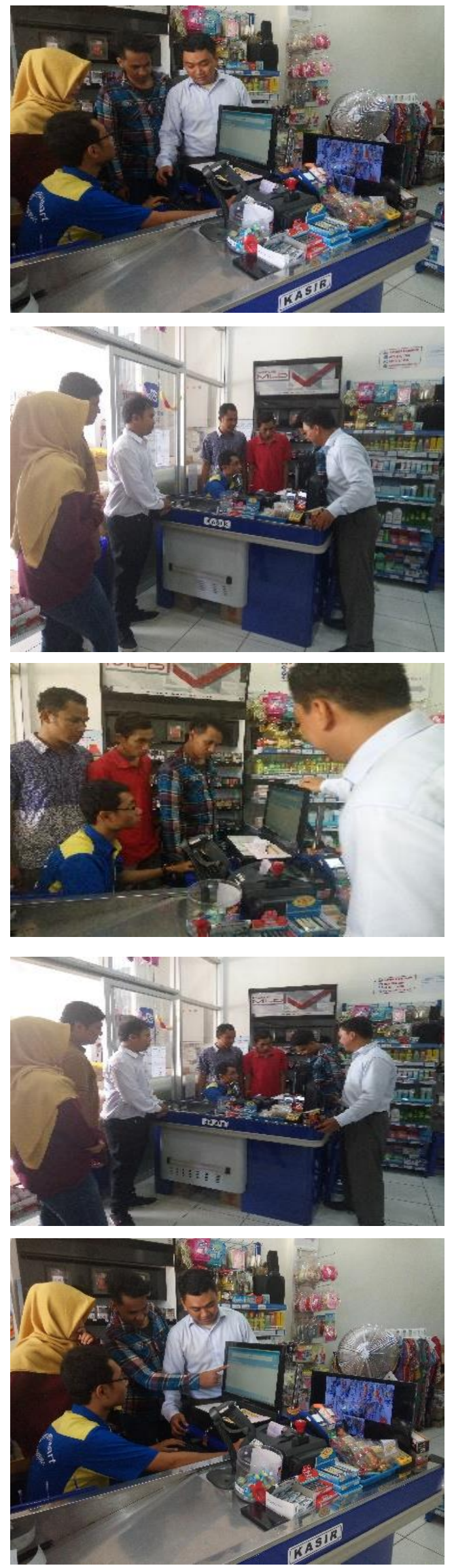

\section{SIMPULAN}

Capaian tujuan yang diharapkan, maka pelaksanaan pelatihan penggunaan aplikasi ini menggunakan tiga cara, yaitu penjelasan materi dan tutorial penggunaan, praktek mandiri dan tanya jawab. Dari hasil pelatihan yang diadakan dapat menarik kesimpulan bahwa peserta pelatihan masih belum bisa mengoperasikan aplikasi jasa kurir online, setalah dilakukan pelatihan peserta mampu pengoperasikan dan menjalan aplikasi jasa kurir online dilihat dari praktek yang dilaksanakan dan yang diadakan $88 \%$ peserta sudah dapat mengoperasikan dan mengaplikasikan materi yang diberikan.

\section{DAFTAR PUSTAKA}

Riyanto. 2014. Membuat Aplikasi mini market integrasi barcode reader dengan php \& mysql. Gaya Media.Yogyakarta.

Santoso,H. Multiplikasi Menggunakan Visual Basic 6. PT.Elex Media Komputindo. Jakarta (2009). Aplikasi Web dengan PHP dan $M y S Q L$. Yogyakarta: ANDI.

Peranginangin, K. (2006). Aplikasi WEB dengan $P H P$ dan $M Y S Q L$. Yogyakarta: ANDI.

Permana, B., \& dkk. (2011). Aplikasi Pengolahan Data Produksi Berbasis Web Di PT. Telehouse 
Tantu Oktavia.Perancangan Model Data Warehouse Dalam Mendukung Perusahaan Jasa Pengiriman.Seminar Nasional Informatika (semnasIF 2011).UPN Vetaran Yogyakarta. 2011

Arip Aryanto, Tri Irianto Tjendrowasono. Pembangunan Sistem Penjualan Online Pada Toko Indah Jaya Furniture
Surakarta.Jurnal Speed-Sentra Penelitian Engineering dan Edukasi. Volume 4. No.4 2012

Ida Astarina, Berliana Kusuma Riasti, (2012), Pembuatan Sistem Penjualan Online Pada Toko Pn Musik Sukoharjo, Jurnal Speed 13Vol 2 No.2 ISSN:9772088015

Subekti, M.(1997). Sistem Manajemen Basis Data. Jakarta: Universitas Bina Darma 